\title{
BARK BEETLES IN A MIXED PLANTATION OF Bertholletia excelsa AND Hevea brasiliensis IN THE SOUTHERN AMAZON
}

\section{SCOLYTINAE EM PLANTIO MISTO DE Bertholletia excelsa $e$ Hevea brasiliensis NA AMAZONIA MERIDIONAL}

\author{
Marcelo MONTEIRO ${ }^{1}$; Juliana GARLET ${ }^{2}$; Camila Craus CARVALHO ${ }^{3}$ \\ 1. Mestre em Biodiversidade e Agroecossistemas Amazônicos, Secretaria de Educação do Estado de Mato Grosso - Matupá, MT, \\ Brasil. marcelobioengflorestal@gmail.com; 2. Professora Adjunta, Faculdade de Ciências Biológicas e Agrárias, Programa de Pós- \\ Graduação em Biodiversidade e Agroecossistemas Amazônicos Universidade do Estado de Mato Grosso, Campus de Alta Floresta, MT, \\ Brasil. julianagarlet@ unemat.br; 3. Graduação em Engenharia Florestal, Universidade do Estado de Mato Grosso, Campus de Alta \\ Floresta, MT, Brasil. camilacrausef@gmail.com
}

\begin{abstract}
Bark beetles (Curculionidae: Scolytinae) are wood borers with the potential to cause significant damage in forest plantations. Studies of this group are more common in plantations of Eucalyptus, and Pinus, but the increase of planting with other forest species, such as Brazil nut and rubber trees, indicates the need for monitoring of Scolytinae in these additional forest areas. Thus, the objective of this work was to evaluate an assemblage and the main species of bark beetles in a mixed plantation of Brazil nut trees (Bertholletia excelsa Bonpl.) and rubber trees (Hevea brasiliensis (Willd. ex A.Juss.) Müll.Arg.) in Southern Amazonia. Twelve ethanol traps were used and collections were carried out biweekly for one year. The collections were evaluated descriptively way with entomofaunistic analysis, and population fluctuation and its dispersion were determined. A total of 2,738 individuals were collected, with a total of 17 species distributed in nine genera, of which Cryptocarenus Eggers 1937 and Xyleborus Eichoff 1864 showed the greatest representation. Cryptocarenus diadematus Eggers, Cryptocarenus heveae (Hagedorni), Cryptocarenus seriatus Eggers, Xyleborus affinis Eichhoff, and Xyleborus spinulosus Blandford were categorized as dominant, very abundant, very frequent, and constant. The assemblage of Scolytinae in the Brazil nut tree and rubber tree mixed plantation had a greater abundance in the rainy season, with the highest averages and population peaks. The species with the greatest representation also presented a greater number of individuals in the rainy season with aggregate dispersion.
\end{abstract}

KEYWORDS: Coleoborers. Forest entomology. Ethanol trap.

\section{INTRODUCTION}

The cultivation of the genus Hevea Aubl. (Euphorbiaceae) is an important economic branch in the Brazilian forestry sector with plantations covering around 229,000 hectares (IBÁ, 2016). The economic importance of Hevea is due to the extraction of latex, indispensable for the manufacture of a wide variety of products, with the states of São Paulo, Mato Grosso, and Bahia being the largest producers (ABRAF, 2011). However, Hevea cultivation has decreased in recent years, and with the decline of rubber exploitation, other native forest species have been cultivated in monoculture or mixed crops, such as the Brazil nut tree (Bertholletia excelsa Bonpl.: Lecythidaceae).

Considering the ecological characteristics and economic potential of the Brazil nut tree, several Bertholletia excelsa planting initiatives have been developed in the Amazon region, either for the recovery of degraded areas, agroforestry systems, and mixed or homogeneous plantations for the production of wood and extractive purposes (SCHROTH et al., 2015).

In forest plantations, constant monitoring of the associated entomofauna is necessary, because crops with few forest species are more susceptible to the attack of pest species. Of these, the class Hexapoda contains several groups that are considered bioindicators, with a great diversity of species and habitats and a significant importance in the biological processes of ecosystems (BERTI FILHO, 1995).

In this context, the bark beetle, with approximately 6,000 species of Scolytinae distributed in 181 genera, constitutes one of the largest groups of Coleoptera. Scolytinae, commonly known as bark and ambrosia beetles, colonize and live in dead trees, with some species responsible for widespread mortality of coniferous and deciduous trees in forests, prevalent in tropical regions (WOOD, 1982; MARINONI et al., 2001; GANDHI et al., 2010; CAJAIBA; SILVA.PÉRICO, 2018). 
Considering the damage the Scolytinae can cause in natural or cultivated ecosystems, there is a need for constant monitoring. The study of the occurrence of insects of this group in a certain place is achieved through ethanol traps, where alcohol simulates the fermented phloem of a tree that the insect attacks. Ethanol is a compound that is released by both senescent and dead trees, which are the main food source of these coleopteran species. Thus, through samplings, population estimates are acquired, making it possible to obtain information about the health of the forest area, as well as the ecology of the insects (MURARI et al., 2012, CARVALHO, TREVISAN, 2015, MACHADO, COSTA, 2017).

According Cajaiba, Silva e Périco (2018), in the Amazon biome, Scolytinae were found to attack several forests and fruit trees. But, studies with coleoborers in forest environments, both native and cultivated, in southern Amazonia in Mato Grosso are still emerging, with research carried out mainly in areas of native forest (MEURER et al., 2013; SILVA, 2009).

The objective of this work was to evaluate an assemblage of bark beetle (Curculionidae: Scolytinae), and identify the main species collected in Brazil nut tree (Bertholletia excelsa) and rubber tree (Hevea brasiliensis (Willd. ex A.Juss.) Müll.Arg.) mixed plantations in southern Amazonia in Alta Floresta, Mato Grosso, Brazil.

\section{MATERIAL AND METHODS}

This study was carried out from August 2015 to August 2016, in a Brazil nut tree (Bertholletia excelsa) and rubber tree (Hevea brasiliensis) mixed plantation in southern Amazonia in the northern region of the state of Mato Grosso, $880 \mathrm{~km}$ from Cuiabá, in the municipality of Alta Floresta-MT, Brazil.

According to Alvares et al. (2014), the climate of the region is classified as Aw, with dry winters. Average annual temperature is above $26^{\circ} \mathrm{C}$, with an annual precipitation between 2,800 and $3,100 \mathrm{~mm}$.

The mixed plantation containing Brazil nut and rubber trees was 15 years old and covered an area of 27.72 ha, with no latex exploitation from individual rubber trees. There was a spacing of 20 meters between rows of Brazil nut trees, with a central line of rubber trees and five meters spacing between rubber trees.

In the survey, we used ethanol impact traps, model Carvalho 47 (CARVALHO, 1998), with some adaptations (GONÇALVES et al., 2014). The alcohol used as attractive bait was $92.8 \%$. In the lower portion of the trap, a plastic container was attached to store collected insects. There were a total of 12 traps, $50 \mathrm{~m}$ apart, and $100 \mathrm{~m}$ between, according to Figure 1. The traps were installed at a height of $1.5 \mathrm{~m}$ (DORVAL et al., 2004). Every 2 weeks, the insects were removed, and the bait and preservation solution renewed.

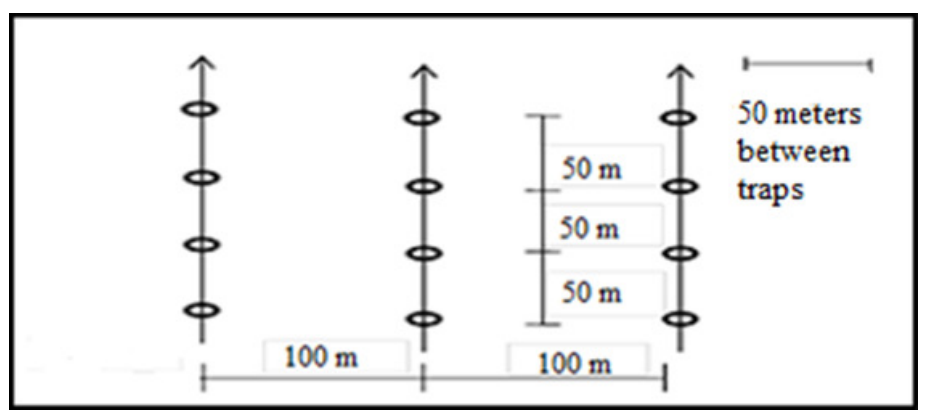

Figure 1. Distribution of the traps in the Brazil nut tree and rubber tree mixed plantation, Alta Floresta, MT, 2015/2016.

Captured individuals were quantified by direct counting. Annotations of the insect quantities included collection site, date of collection, and location of the traps. The collected insects were stored in plastic containers, identified to the most precise taxonomic level possible, and sent to the Laboratory of the State University of Mato Grosso, Campus Alta Floresta, where sorting and separation of the material was carried out. Subsequently, the specimens were sent to the Federal University of
Paraná for identification by Professor Eli Nunes Marques.

We used daily meteorological data of temperature, relative humidity based on biweekly measurements, and precipitation data to evaluate the influence of environmental variables on bark beetle assemblages. Data were obtained from the meteorological station of the State University of Mato Grosso, Campus II (August 2015 to August 2016). 
Due to the high variability of the data, it was necessary to transform the counts for each species. The variables analyzed in this study were initially submitted to the Lilliefors test to evaluate the normality of the data. As the data were not considered normal, the $\log (x+1)$ transformation was used, in order to meet the assumptions of the parametric tests.

The mean test was performed to analyze the influence of climatic periods (drought and rainfall) on abundance and richness. A completely randomized design was used in a factorial arrangement, with a factorial $17 \times 2$ design (17 species for two climatic periods, with twelve traps/replicates). The averages were submitted to analysis of variance and compared by the T-test ( $\mathrm{p} \leq$ $0.05)$, using the SISVAR computational resource version 4.0 (FERREIRA, 2000).

Analysis of variance and T-test $(\mathrm{p} \leq 0.05)$ were performed for the log-transformed means of the different factors. The mean test was applied to verify differences between the data, as well as species groupings, regarding their distribution among the seasonal periods (dry and rain).

We also calculated the faunistic indices of constancy, dominance, frequency, and abundance for the periods of drought and rainfall, using the software Past (HAMMER et al., 2001). The Shannon-Wiener Diversity ( $\mathrm{H}$ '), Margalef diversity $(\alpha)$, and equitability (E) were calculated for the climatic periods of drought and rainfall in the respective environment.

Population fluctuation was analyzed only for the species that occurred in the faunistic analysis as dominant, very abundant, very frequent, and constant. We also calculated the spatial dispersion for the bark beetle species collected in native forest, using the indices of Morisita (I $\delta$ ) and Green (Cx) ratios (MORISITA, 1962).

Pearson's correlation $(r) \quad(p \leq 0$. 05) was calculated between the three populations and maximum, mean, minimum, relative humidity, and rainfall. This study was carried out only with species that occurred in the faunistic analysis as dominant, very abundant, very frequent, and constant. For this analysis, we used the software package R (R Core Development Team, 2012).

\section{RESULTS AND DISCUSSIONS}

A total of 2,738 individuals were collected, with a total of 17 species distributed in nine genera, with a greater representation of Cryptocarenus and Xyleborus (Table 1). The species Xyleborus affinis Eichhoff, Cryptocarenus seriatus Eggers, Cryptocarenus heveae Hagedorni, and Cryptocarenus diadematus Eggers were the most collected species, totaling 1,435 individuals. Regarding the dominance, 13 species were dominant and four were non-dominant. In terms of abundance, five species were very abundant, seven species were rare, three were common, and two were dispersed. Nine species were infrequent, three frequent, and five very frequent, while eight species were constants, four accessory, and five accidentals. The species Cryptocarenus diadematus, Cryptocarenus heveae, Cryptocarenus seriatus, Xyleborus affinis, Xyleborus spinulosus were dominant, very abundant, very frequent, and constant, respectively, while Cnesinus dryografus and Hypotenemus eruditus were dominant, common, frequent, and constant.

Table 1. Entomofaunistic indices for the bark beetles collected with an impact ethanol trap in the Brazil nut tree (Bertholletia excelsa) and rubber tree (Hevea brasiliensis) mixed plantation in Alta Floresta-Mato Grosso, Brazil.

\begin{tabular}{llllll}
\hline Species & Dom & A & F & Con & Total \\
\hline *Cryptocarenus diadematus Eggers & D & Ma & MF & W & 322 \\
$*$ Cryptocarenus heveae Hagedorni & D & Ma & MF & W & 332 \\
$*$ Cryptocarenus seriatus Eggers & D & Ma & MF & W & 374 \\
Cnesinus dryografus Schedl & D & C & F & W & 60 \\
Coccotrypes palmarum Eggers & ND & R & PF & Z & 25 \\
Hypotenemus bolivianus Eggers & D & R & PF & Y & 19 \\
Hypotenemus eruditus Westwood & D & C & F & W & 102
\end{tabular}




\begin{tabular}{|c|c|c|c|c|c|}
\hline Hypotenemus seriatus Eichhoff & $\mathrm{D}$ & $\mathrm{D}$ & $\mathrm{PF}$ & $\mathrm{Y}$ & 41 \\
\hline $\begin{array}{l}\text { Premnobius cavipennis (Eichhoff, } \\
\text { 1878) }\end{array}$ & $\mathrm{D}$ & $\mathrm{R}$ & $\mathrm{PF}$ & $\mathrm{Z}$ & 23 \\
\hline Trycolos sp. & ND & $\mathrm{R}$ & $\mathrm{PF}$ & $\mathrm{Z}$ & 3 \\
\hline Xyleborinus reconditus Schedl & ND & $\mathrm{R}$ & $\mathrm{PF}$ & $\mathrm{Z}$ & 4 \\
\hline Xyleborus affinis Eichhoff & $\mathrm{D}$ & $\mathrm{Ma}$ & $\mathrm{MF}$ & $\mathrm{W}$ & 407 \\
\hline Xyleborus ferrugineus Fabricius & $\mathrm{D}$ & $\mathrm{C}$ & $\mathrm{F}$ & $\mathrm{Y}$ & 137 \\
\hline Xyleborus spinulosus Blandford & $\mathrm{D}$ & $\mathrm{Ma}$ & MF & W & 210 \\
\hline Xyleborus truncatellus Schedl & ND & $\mathrm{R}$ & $\mathrm{PF}$ & $\mathrm{Z}$ & 22 \\
\hline Xylosandrus curtulus Eichhoff & $\mathrm{D}$ & $\mathrm{R}$ & $\mathrm{PF}$ & $\mathrm{Y}$ & 20 \\
\hline Xylosandrus germanus Blandford & $\mathrm{D}$ & $\mathrm{D}$ & $\mathrm{PF}$ & W & 37 \\
\hline Equitabilidade (E) & \multicolumn{2}{|c|}{ Margalef $(\alpha)$} & \multicolumn{3}{|c|}{ Shannon-Wiener $(\mathrm{H})$} \\
\hline 0.77 & \multicolumn{2}{|c|}{2.02} & \multicolumn{3}{|c|}{2.18} \\
\hline
\end{tabular}

Dom: (D) Dominant; (Nd) non-dominant. A: Abundance - (Ma) very abundant; (C) common; (D) dispersed; (R) rare. F: Frequency - (mf) very frequent; (F) frequent; (Pf) infrequent. Con: Constancy - (w) constant; (Y) accessory; (Z) accidental, (Total) total collected, $(*)$ individuals chosen for correlation between population fluctuation and climatic factors.

The results observed in this work are in agreement with the findings of Flechtmann and Ottati (1996) in Cerrado vegetation, in which the species Hypotenemus eruditus, Xyleborus spinulosus, and two species of the genus Cryptocarenus also occurred most as dominant, abundant, frequent, and constant.

The species Xyleborus spinulosus had a preference for a wide variety of hosts and has been registered by other researchers in native forest areas (DORVAL; PERES FILHO, 2001; ROCHA et al., 2011b; ABREU et al., 2012) and in rubber plantations (DALL OGLIO; PERES FILHO, 1997; FLECHTMANN; GASPARETO, 1997), demonstrating its wide occurrence in different forest ecosystems.

The species Premnobius cavipennis was dominant, rare, infrequent, and accidental. Our results are similar those observed by Bastos (2013), in which the species Cryptocarenus diadematus, Hypotenemus eruditus, Premnobius cavipennis and Xyleborus affinis were dominant in native forest in the municipality of Campo Verde-MT.

In this plantation, as seen in Table 1 , species equitability (E) was 0.77 , with a Margalef $(\alpha)$ richness index of 2.02 and a Shannon-Wiener $(\mathrm{H})$ index of 2.18. A previous study by Rocha et al. (2011c) in the municipality of Cuiabá with unchanged remnant Cerrado vegetation, observed that annual equitability (E) was 0.72 , Margalef $(\alpha)$ diversity was 3.54, and Shannon-Wiener $(\mathrm{H})$ index was 2.33 . Their equitability value is similar to that of this study, but with higher values of diversity.

Collections in the plantation were performed year round, and Cryptocarenus diadematus showed a well-distributed population peak from January to April, with an increase in June and July (Fig. 2). In the same way, Cryptocarenus heveae peaked in February and March, with an increase in July. The species Cryptocarenus seriatus was highly increased in October, January, March, and June.

Januário et al. (2013) reinforced the idea that planted forests can present larger numbers of individuals than natural forests, albeit with an irregular distribution of individuals, which leads to disorderly population outbreaks and low diversity in the environment. Studying coleoborers in Hevea brasiliensis in the state of Mato Grosso, Dall'oglio and Peres Filho (1997) found population peaks of $C$. heveae species in the months of july and august, working with different vegetation systems in two agroforestry systems and rubber tree planting.

The population of Cryptocarenus diadematus was correlated with all variables analyzed in the plantation; precisely, it correlated negatively with the maximum and average temperatures and positively with the minimum temperature, relative humidity of the maximum air, minimum, and with rainfall. The population of 
Cryptocarenus heveae correlated negatively with mean and maximum temperature and positively with minimum relative humidity. There was a positive correlation with the Cryptocarenus seriatus population only with rainfall (Table 2).

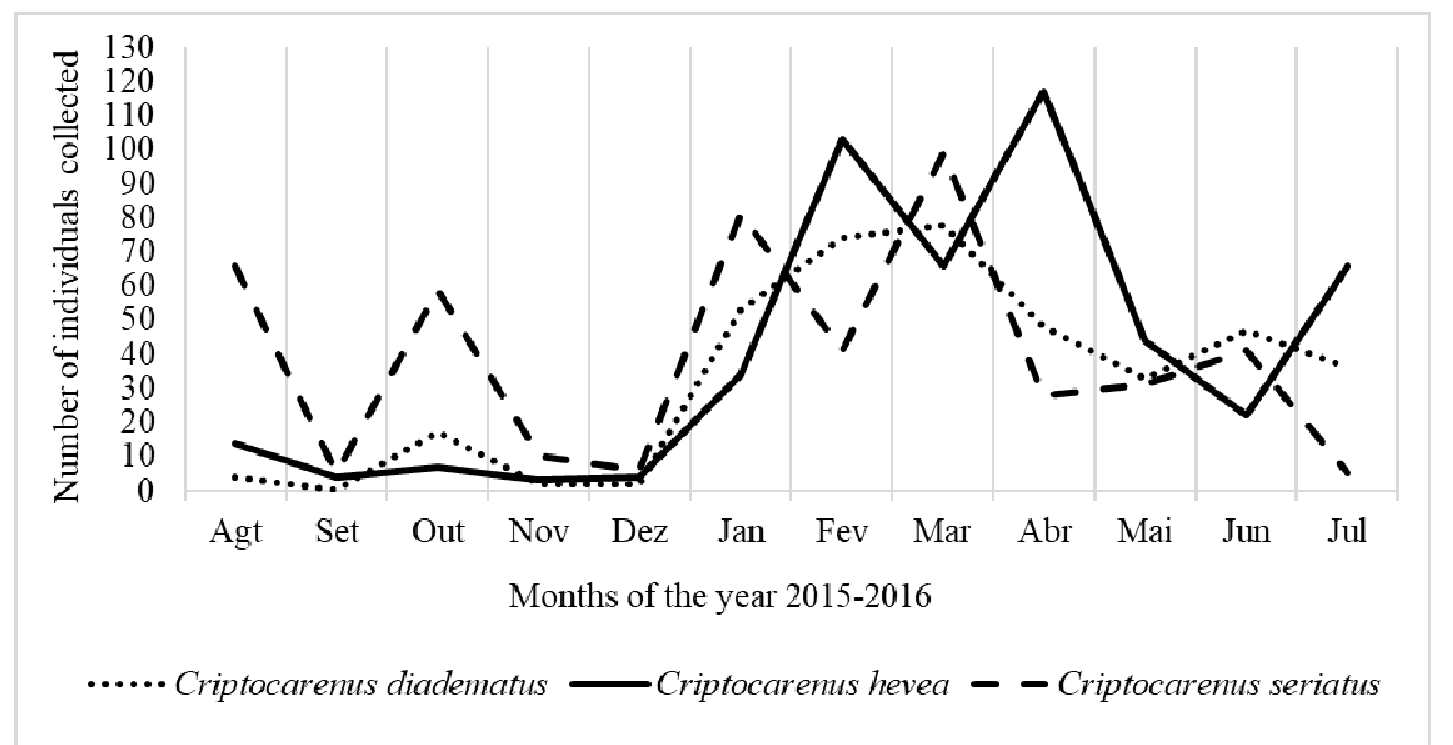

Figure 2. Population fluctuation of the bark beetle in the Brazil nut tree and rubber tree mixed plantation in the municipality of Alta Floresta, Mato Grosso, Brazil.

Table 2. Correlation between the population fluctuation of selected bark beetle and climatic factors in a Brazil nut tree and rubber tree mixed plantation, Alta Floresta, Mato Grosso, Brazil.

\begin{tabular}{|c|c|c|c|c|c|c|}
\hline Species & Average & $\begin{array}{l}\text { Maximum } \\
\text { temperature }\end{array}$ & $\begin{array}{l}\text { Minimum } \\
\text { temperature }\end{array}$ & $\begin{array}{l}\text { Maximum } \\
\text { humidity }\end{array}$ & $\begin{array}{l}\text { Minimum } \\
\text { humidity }\end{array}$ & Precipitation \\
\hline $\begin{array}{l}\text { Cryptocarenus } \\
\text { diadematus }\end{array}$ & $-0.70^{*}$ & $-0.76^{*}$ & $0.53 *$ & $0.54 *$ & $0.73 *$ & $0.62 *$ \\
\hline $\begin{array}{l}\text { Cryptocarenus. } \\
\text { heveae }\end{array}$ & $-0.55^{*}$ & $-0.54^{*}$ & $0.37^{\mathrm{NS}}$ & $0.40^{\mathrm{NS}}$ & $0.54 *$ & $0.32^{\mathrm{NS}}$ \\
\hline $\begin{array}{l}\text { Cryptocarenus } \\
\text { seriatus }\end{array}$ & $-0.34^{\mathrm{NS}}$ & $-0.45^{\mathrm{NS}}$ & $0.38^{\mathrm{NS}}$ & $0.22^{\mathrm{NS}}$ & $0.40^{\mathrm{NS}}$ & $0.69 *$ \\
\hline
\end{tabular}

Dall'oglio and Peres Filho (1997), using ethanol traps in rubber plantations (Hevea brasiliensis) in the municipality of Itiquira-Mt, observed that most of the species of Scolytinae found favorable environmental conditions, regardless of the presence or absence of rainfall, probably caused by the microclimate of the crop. In our study, analysis of variance revealed significant statistical differences at the $5 \%$ probability for the Scolytinae assay evaluated, with the highest collection average observed in the rainy season (Table 3). Cajaiba, Silva e Périco (2018) also report that the dry season showed lower abundance and species richness, and was statistically shorter than the rainy seasons for an assembly of Scolytinae in the Amazon Biome in northern Brazil. The authors also emphasized that seasonal variations in diversity and composition demonstrated the influence of phenology on survey timing in studying Scolytinae and habitat associations. Moreover, seasonal information on Scolytinae beetle is essential to understand the relevant ecological processes and, thus, the related management aspects.

Two groups of averages occurred in the dry season, with Xyleborus spinulosus, Cryptocarenus seriatus, Cryptocarenus diadematus, Cryptocarenus heveae, and Xyleborus affinis showing the highest averages, respectively (Table 3). The species Trycolos sp., Premnobius cavipennis, and Xyleborus truncatellus were not collected during the dry season. Among the 16 species collected in both periods, Xyleborus reconditus, Xyleborus curtulus, and Xyleborus germanus presented the lowest averages. In the rainy season, four large groups were formed, with high heterogeneity among the species. The species Xyleborus affinis and Cryptocarenus 
seriatus reached the highest averages, while Cryptocarenus heveae and Cryptocarenus diadematus formed a second group of quantitative importance.

Table 3. Testing of means among the species of bark beetles collected in the Brazil nut tree and rubber tree mixed plantation in Alta Floresta, Mato Grosso, Brazil.

\begin{tabular}{|c|c|c|}
\hline \multirow[b]{2}{*}{ Species } & \multicolumn{2}{|l|}{ Average } \\
\hline & Dry season & Rainy season \\
\hline Cnesinus dryografus & $1.75 \mathrm{bA}$ & $3.16 \mathrm{dA}$ \\
\hline Cryptocarenus diadematus & $6.75 \mathrm{aB}$ & $18.58 \mathrm{bA}$ \\
\hline Cryptocarenus heveae & $6.58 \mathrm{aB}$ & $21.91 \mathrm{bA}$ \\
\hline Cryptocarenus seriatus & $9.66 \mathrm{aB}$ & $23.66 \mathrm{aA}$ \\
\hline Hypotenemus bolivianus & $0.08 \mathrm{bA}$ & $1.50 \mathrm{dA}$ \\
\hline Hypotenemus eruditus & $0.58 \mathrm{bB}$ & $8.75 \mathrm{cA}$ \\
\hline Hypotenemus seriatus & $0.75 \mathrm{bA}$ & $2.66 \mathrm{dA}$ \\
\hline Preminobius cavipenis & - & $1.91 \mathrm{dA}$ \\
\hline Trycolos sp. & - & $0.25 \mathrm{dA}$ \\
\hline Xyleborinus reconditus & $0.25 \mathrm{bA}$ & $0.08 \mathrm{dA}$ \\
\hline Xyleborus affinis & $6.41 \mathrm{aB}$ & $27.41 \mathrm{aA}$ \\
\hline Xyleborus ferrugineus & $2.66 \mathrm{bB}$ & $9.08 \mathrm{cA}$ \\
\hline Xyleborus spinulosus & $9.75 \mathrm{aA}$ & $8.75 \mathrm{cA}$ \\
\hline Xyleborus truncatellus & - & $0.41 \mathrm{dA}$ \\
\hline Xylosandrus curtulus & $0.08 \mathrm{bA}$ & $1.58 \mathrm{dA}$ \\
\hline Xylosandrus germanus & $0.25 \mathrm{bA}$ & $2.83 \mathrm{dA}$ \\
\hline Average of the Scolytinae Assemblage & 75,67 B & $113,07 \mathrm{~A}$ \\
\hline
\end{tabular}

Means followed by the same capital letter in the row and the same lowercase letter in the column do not differ at the 5\% probability level by the T-test.

The results of this work are in agreement with the findings of Rocha et al. (2011a), who obtained six groupings of averages in their annual evaluation, with Xyleborus affinis in the rainy season having the highest average. Pérez-De La Cruz et al. (2016), in a conservation area in Tabasco, Mexico, observed that the species Xyleborus affinis had the greatest abundance in the total collection. Lunz and Carvalho (2002) analyzed six forest species in the municipality of Seropédica, State of Rio de Janeiro, and noticed a high frequency of Xyleborus affinis and Xyleborus ferrugineus in wood samples.

As for the dispersion of the collected species, we observed that Trycolos sp. obtained uniform distribution, according to the three 
dispersion indices. A plausible explanation is that the species had a low representation in the three collection environments. For all other species, the index values were higher than 1 , with aggregate distribution (Table 4).

Table 4. Scatter rates of the total species collected in the Brazil nut tree and rubber tree mixed plantation in Alta Floresta, Mato Grosso, Brazil.

\begin{tabular}{llll}
\hline Species & Morisita & Var-media & Green \\
\hline Cnesinus dryografus & $1.63^{\text {agr }}$ & $4.4^{\text {agr }}$ & $0.057^{\text {agr }}$ \\
Coccotrypes palmarum & $2.2^{\text {agr }}$ & $3.62^{\text {agr }}$ & $0.1^{\text {agr }}$ \\
Cryptocarenus diadematus & $1.18^{\text {agr }}$ & $6.35^{\text {agr }}$ & $0.016^{\text {agr }}$ \\
Cryptocarenus heveae & $1.2^{\text {agr }}$ & $7.02^{\text {agr }}$ & $0.018^{\text {agr }}$ \\
Cryptocarenus seriatus & $1.26^{\text {agr }}$ & $9.85^{\text {agr }}$ & $0.023^{\text {agr }}$ \\
Hypotenemus bolivianus & $1.33^{\text {agr }}$ & $1.55^{\text {agr }}$ & $0.03^{\text {agr }}$ \\
Hypotenemus eruditus & $1.08^{\text {agr }}$ & $1.81^{\text {agr }}$ & $0.007^{\text {agr }}$ \\
Hypotenemus seriatus & $2.07^{\text {agr }}$ & $4.92^{\text {agr }}$ & $0.098^{\text {agr }}$ \\
Preminobius cavipenis & $2.03^{\text {agr }}$ & $3.08^{\text {agr }}$ & $0.094^{\text {agr }}$ \\
Trycolos sp. & $02^{\text {uni }}$ & $0.82^{\text {uni }}$ & $-0.095^{\text {uni }}$ \\
Xyleborinus reconditus & $1.88^{\text {agr }}$ & $1.27^{\text {agr }}$ & $0.09^{\text {agr }}$ \\
Xyleborus affinis & $1.29^{\text {agr }}$ & $43.51^{\text {agr }}$ & $0.08^{\text {agr }}$ \\
Xyleborus ferrugineus & $1.32^{\text {agr }}$ & $7.12^{\text {agr }}$ & $0.026^{\text {agr }}$ \\
Xyleborus spinulosus & $3.32^{\text {agr }}$ & $5.44^{\text {agr }}$ & $0.029^{\text {agr }}$ \\
Xyleborus truncatellus & $1.83^{\text {agr }}$ & $2.44^{\text {agr }}$ & $0.21^{\text {agr }}$ \\
Xylosandrus curtulus & $3.89^{\text {agr }}$ & $10.46^{\text {agr }}$ & $0.075^{\text {agr }}$ \\
Xylosandrus germanus & & $0.26^{\text {agr }}$ \\
\hline
\end{tabular}

Uniform (uni); Aggregate (agr); Random (R)

Similar results of the dispersion of the species collected in this study were found in other studies for different species, such as Rhynchophorus palmarum Linnaeus (Coleoptera: Curculionidae) in oil palm (Elaeis guineensis Jacq.) in the State of Pará (PINHO et al., 2016), Empoasca kraemeri (Hemiptera: Cicadellidae) in Jatropha curcas L, in Dourados-MS (OLIVEIRA et al., 2016), Spodoptera frugiperda (Lepidoptera: Noctuidae) in corn crop in Dourados-MS (MELO et al., 2014), Aphis gossypii (Hemiptera, Aphididae) and Bemisia tabaci biotype B (Hemiptera, Aleyrodidae) in cotton crops in an agricultural area in Caarapó-MS (RODRIGUES et al., 2010), and Oncometopia facialis (Signoret) (Hemiptera: Cicadellidae) in citrus in Taquaritinga, SP (MARUYAMA et al., 2006), and presented the same aggregation pattern.

This aggregation can be a result of the pheromones that are usually produced by male insects and attract both sexes (CROSS; MITCHELL, 1966). These aggregation pheromones have been used for the mass capture of coleoborers of the family Curculionidae (ZARBIN et al., 2007).

\section{CONCLUSIONS}

Based on the results of this study, the assemblage of Scolytinae in the Brazil nut tree and rubber tree mixed plantation presented a total of 17 species distributed in nine genera with a greater representation of Cryptocarenus and Xyleborus. The Scolytinae abundance was higher in the rainy season, with the highest averages and the highest population peaks.

In the entomofaunistic analysis, Cryptocarenus diadematus, Cryptocarenus heveae, Cryptocarenus seriatus, Xyleborus affinis and Xyleborus spinulosus were dominant, very abundant, very frequent, and constant in the plantation. And these species presented a greater number of individuals in the rainy season with aggregate dispersion.

\section{ACKNOWLEDGEMENTS}

We thank the State University of Mato Grosso (UNEMAT) and CAPES for providing a Master's scholarship to the first author, and the 
FAPEMAT for the scholarship to the third author. We also thank Professor Dr. Eli Nunes Marques of the Federal University of Paraná for identification of the material collected.

RESUMO: Scolytinae são coleobrocas com potencial de causar significativos danos em plantios florestais. Estudos com este grupo são mais comuns em plantios de Eucalyptus e Pinus, mas o aumento das áreas de plantio com outras espécies florestais como castanheira e seringueira indica a necessidade de monitoramento também dos Scolytinae nestas áreas florestais. Assim, o objetivo deste trabalho foi avaliar uma assembléia e as principais espécies coletadas de escolitíneos (Curculionidae: Scolytinae) em um plantio misto de castanheira (Bertholletia excelsa Bonpl.) e seringueira (Hevea brasiliensis (Willd. ex A.Juss.) Müll.Arg.) na Amazônia Meridional, no município de Alta Floresta, Mato Grosso. As coletas foram realizadas quinzenalmente no período de agosto de 2015 a agosto de 2016, em 12 armadilhas de etanol. A assembléia foi avaliada de maneira descritiva com análises entomofaunisticas, e para as principais espécies determinou-se sua flutuação populacional e dispersão. Um total de 2.738 indivíduos foram coletados, totalizando 17 espécies distribuídas em nove gêneros, dos quais Cryptocarenus Eggers 1937 e Xyleborus Eichoff 1864 foram os mais representativos. $\mathrm{Na}$ análise entomofaunística, Cryptocarenus diadematus Eggers, Cryptocarenus heveae (Hagedorni), Cryptocarenus seriatus Eggers, Xyleborus affinis Eichhoff e Xyleborus spinulosus Blandford foram dominantes, muito abundantes, muito frequentes e constantes. A assembléia de Scolytinae no plantio misto de castanheira com seringueira, apresentou maior abundância na estação chuvosa, com as maiores médias e picos populacionais. E as principais espécies coletadas também apresentaram maior número de indivíduos coletados na estação chuvosa com dispersão agregada.

PALAVRAS-CHAVE: Coleobrocas. Entomologia Florestal. Aramadilha Etanólica.

\section{REFERENCES}

\section{ABRAF (ASSOCIAÇÃO BRASILEIRA DE PRODUTORES DE FLORESTAS PLANTADAS). Anuário Estatístico da ABRAF 2011 ano base 2010. Brasília: Abraf, 2011, 130p.}

ABREU, R. L. S.; RIBEIRO, G. A.; VIANEZ, B. F.; CAMPOS, C. S. Insects of the subfamily Scolytinae (Insecta: Coleoptera, Curculionidae) collected with pitfall and ethanol traps in primary forests of Central Amazonia. Psyche: A Journal of Entomology, Cambrigde, v. 2012, p. 1-9, 2012. http://dx.doi.org/10.1155/2012/480520.

ALVARES, C. A.; STAPE, J. L.; SENTELHAS, P. C.; GONÇALVES, J. L. M.; GERD SPAROVEK, G. Koopen's climate classification map for Brazil. Meteorologische Zeitschrift, Stuttgart, v. 22, n. 6, p. 711-728, 2014. http://dx.doi.org/10.1127/0941-2948/2013/0507

BASTOS, E. A. S. Influência da concentração de etanol na coleta de Scolytineos (Coleoptera, Curculionidae) em área de Mata Nativa no município de Campo Verde-MT. 2013. 57 f. Dissertação (Mestrado em Ciências Florestais e Ambientais) - Curso de Pós-Graduação em Ciências Florestais e Ambientais, Universidade Federal de Mato Grosso, Cuiabá, 2013.

BERTI FILHO, E. Cupins e Florestas. In: BERTI FILHO, E.; FONTES, L. R. Alguns aspectos atuais da biologia e controle de cupins. Piracicaba: Fundação de Estudos Agrários Luiz de Queiroz, 1995, p. 127-140.

CARVAlHO, A. G. Armadilha modelo Carvalho-47. Revista Floresta e Ambiente, Seropédica, v. 5, n. 1, p. 225-227,1998.

CARVALHO, A. G.; TREVISAN, H. Novo Modelo de Armadilha para Captura de Scolytinae e Platypodinae (Insecta, Coleoptera). Revista Floresta e Ambiente, Seropédica, v. 22, n. 4, p. 575-578, 2015. http://dx.doi.org/ 10.1590/2179-8087.105114. 
CAJAIBA, R. L.; SILVA, B. W.; PÉRICO, E. Diversity of Scolytinae (Coleoptera: Curculionidae) in different landscapes in northern Brazil. Neotropical Biology and Conservation, São Leopoldo, v. 13, n. 1, p. 10-16, 2018. http://dx.doi.org/ 10.4013/nbc.2018.131.02

CROSS, W. H.; MITCHELL, H. C. Mating behavior of the female boll weevil. Journal of Economic Entomology, Annapolis, v. 59, n. 6, p. 1503-1507,1966. https://doi.org/10.1093/jee/59.6.1503

DALL'OGLIO, O. T.; PERES-FILHO, O. Levantamento e flutuação populacional de coleobrocas em plantios homogêneos de seringueira em Itiquira - MT. Scientia Forestalis, Piracicaba, n. 51, p. 49-58, 1997.

DORVAL, A.; PERES FILHO, O. Levantamento e flutuação populacional de coleópteros em vegetação do cerrado da Baixada Cuiabana, MT. Ciência Florestal, Santa Maria, v. 11, n. 2, p. 170-182, 2001. https://doi.org/10.5902/198050981665

DORVAL, A.; PERES-FILHO O.; MARQUES E. N. Levantamento de Scolytidae (Coleoptera) em plantações de Eucalyptus spp. em Cuiabá, estado de Mato Grosso. Ciência Florestal, Santa Maria, v. 14, n. 1, p. 47-58, 2004. https://doi.org/10.5902/198050981780

FERREIRA, D. F. Sisvar: a computer statistical analysis system. Ciência e Agrotecnologia, Lavras, v. 35, n. 6, p. 1039-1042, 2011. http://dx.doi.org/10.1590/S1413-70542011000600001

FLECHTMANN, C. A. H.; GASPARETO, C. L. Scolytidae em pátio de serraria da fábrica Paula Souza (Botucatu/SP) e fazenda Rio Claro (Lençóis Paulista/SP). Scientia Forestalis, Piracicaba, v. 51, n. 2, p. 61-75, 1997.

FLECHTMANN, C. A. H.; OTTATI, A. L. T. Scolytidae em area de mata nativa em Selvíria, MS, Brasil. Anais da Sociedade Entomológica do Brasil, Londrina, v. 25, n. 2, p. 365-368, 1996.

GANDHI, K. J. K.; COGNATO, A. I.; NIELSEN, D. G.; HERMS, D. A. 2010. Species Composition, Seasonal Activity, and Semiochemical Response of Native and Exotic Bark and Ambrosia Beetles (Coleoptera: Curculionidae: Scolytinae) in Northeastern Ohio. Journal of Economic Entomology, v. 103, n. 4, p. $1187-$ 1195. http://dx.doi.org/10.1603/EC10026

GONÇALVES, F. G.; CARVALHO, A. G.; CARDOSO, W. V. M.; RODRIGUES, C.S.R. Coleópteros broqueadores de madeira em ambiente natural de Mata Atlântica e em plantio de eucalipto. Pesquisa Florestal Brasileira, Colombo, v. 34, n. 79, p. 245-250, 2014. https://doi.org/10.4336/2014.pfb.34.79.49

HAMMER, O.; HARPER, D. A. T.; RIAN, P. D. PAST: Paleontological statistics software package for education and data analysis. Paleontology Electronic, v. 4, n. 1, p. 1-9, 2001.

IBA - INDÚSTRIA BRASILEIRA DE ÁRVORES. Relatório anual IBÁ. São Paulo: 2016. 100 p.

JANUÁRIO, S. B. S.; PERES FILHO, O. SOUZA, M. D.; DORVAL, A.; SILVA, M. N. Caracterização da família Geometridae (Insecta: Lepidoptera) associada a diferentes fragmentos florestais, em Cotriguaçu, MT. Pesquisa Florestal Brasileira, Colombo, v. 33, n. 76, p. 395-404, 2013.

http://dx.doi.org/10.4336/2013.pfb.33.76.399

LUNZ, A. M.; CARVALHO, A. G. Degradação da madeira de seis essências arbóreas dispostas perpendicularmente ao solo, causada por Scolytidae (Coleoptera). Neotropical Entomology, Londrina, v. 31, n. 3, p. 351-357, 2002. http://dx.doi.org/10.1590/S1519-566X2002000300002.

MACHADO, L. M.; COSTA, E. C. Altura de voo de escolitíneos (coleoptera, scolytinae) em povoamento de Pinus taeda L. no sul do Brasil. Revista Ciência Florestal, Santa Maria, v. 27, n. 2, p. 669-678. 2017. http://dx.doi.org/10.5902/1980509827751. 
MARINONI, R. C.; GANHO, N. G.; MONNÉ, M. L.; MERMUDES. J. R. M. Hábitos alimentares em Coleoptera (Insecta). Ribeirão Preto: Holos, 2001. 63p.

MARUYAMA, W. I.; BARBOSA, J. C.; TOSCANO, L. C. Distribuição Espacial de Oncometopia facialis (Signoret) (Hemiptera: Cicadellidae) em Pomar Cítrico. Neotropical Entomology, Londrina, v. 35, n. 1, p. 93 100, 2006. http://dx.doi.org/10.1590/S1519-566X2006000100013.

MELO, E. P.; DEGRANDE, P. E.; LIMA JUNIOR, I. S.; SUEKANE, R.; KODAMA, C.; FERNANDES, M. G. Disposição espacial e injúrias da lagarta-do-cartucho Spodoptera frugiperda (J. E. Smith) (Lepidoptera: Noctuidae) em milho. Revista Ceres, Viçosa, v. 61, n. 3, p. 343-349, 2014. http://dx.doi.org/10.1590/S0034737X2014000300007.

MEURER, E.; BATTIROLA, L. D.; COLPANI, D.; DORVAL, A.; MARQUES, M. I.Scolytinae (Coleoptera, Curculionidae) associados a diferentes fitofisionomias no Pantanal de Cáceres, Mato Grosso. Acta Biológica Paranaense, Curitiba, v. 42, n. 3-4, p. 195-210, 2013. https://doi.org/10.5380/abpr.v42i1-4.35214

MORISITA, M. I $\delta$ - index, a measure of dispersion of individuals. Researches on Population Ecology, Kyoto, v. 4, n. 1, p. 1-7, 1962. https://doi.org/10.1007/BF02533903

MURARI, A. B.; COSTA, E. C.; BOSCARDIM, J.; GARLET, J. Modelo de armadilha etanólica de interceptação de vôo para captura de escolitídeos (Curculionidae: Scolytinae). Pesquisa Florestal Brasileira, Colombo, v. 32, n. 69, p. 115-117, 2012. http://dx.doi.org/10.4336/2012.pfb.32.69.115

OLIVEIRA, M. D. G.; FERNANDES, M. G.; MOTA, T. A.; OLIVEIRA, H. N. Distribuição espacial de adultos de Empoasca kraemeri (Hemiptera: Cicadellidae) em pinhão-manso Jatropha curcas L.

Entomotropica, Caracas, v. 31, n. 29, p. 237-243, 2016.

PÉREZ-DE LA CRUZ, M.; HERNÁNDEZ-MAY, M. A.; CRUZ-PÉREZ, A. DE LA.; SÁNCHEZ-SOTO, S. Scolytinae y Platypodinae (Coleoptera: Curculionidae) de dos áreas de conservación en Tabasco, México.

Revista de Biologia Tropical, San José, v. 64, n.1, p 335-342, 2016. https://doi.org/10.15517/rbt.v64i1.15931

PINHO, R. C.; FARIAS, P. R. S.; RODRIGUES, K. C. V.; TINÔCO, R. S.; SANTOS, A. V. F.; MARSSENA, R. T. P. Distribuição espacial de Rhynchophorus palmarum em palma de óleo no Estado do Pará, Amazônia.

Revista de Ciências Agrárias, Recife, v. 59, n. 1, p. 22-31, 2016. https://doi.org/10.4322/rca.2116

R, C. D. R: A language and environment for statistical computing. Vienna. 2012. Disponível em: http://www.rproject.org/. Acesso em: 20 abr. 2017.

ROCHA, J. R. M.; DORVAL, A.; PERES-FILHO, O.; COSTA, R. B. Dinâmica populacional de Bostrichidae, Platypodidae e Scolytidae (Coleoptera) em talhão de Urograndis (Eucalyptus urophylla x Eucalyptus grandis) no município de Cuiabá,Estado de Mato Grosso. Revista de Agricultura (Piracicaba), v. 86, p. 230-242, 2011 a.

ROCHA, J. R. M.; DORVAL, A.; PERES FILHO, O.; SILVA, A. L. Coleópteros (Bostrichidae, Platypodidae e Scolytidae) em um fragmento de cerrado da baixada Cuiabana. Ambiência, Guarapuava, v.7 n.1 p. 89-101, 2011b. https://doi.org/10.5777/ambiencia.2011.01.07

ROCHA, J. R. M. ALMEIDA, R. J.; LINS, A. G.; DORVAL. A. Insects as indicators of environmental changing and pollution: a review of appropriate species and their monitoring. Holos environment, Rio Claro, v. 10, n. 2, p. 250-262, 2011c. https://doi.org/10.14295/holos.v10i2.2996

RODRIGUES, T. R.; FERNANDES, M. G.; SANTOS, H. R. Distribuição espacial de Aphis gossypii (Glover) (Hemiptera, Aphididae) e Bemisia tabaci (Gennadius) biótipo B (Hemiptera, Aleyrodidae) em algodoeiro Bt e não-Bt. Revista Brasileira de Entomologia, Curitiba, v. 54, n. 1, p. 136-143, 2010.

http://dx.doi.org/10.1590/S0085-56262010000100019. 
SCHROTH, G.; MOTA, M.S.S.; ASSIS ELIAS, M.E. Growth and nutrient accumulation of Brazil nut trees (Bertholletia excelsa) in agroforestry at different fertilizer levels. Journal of Forestry Research, Harbin, v. 26, n. 2, p. 347-353, 2015. https://doi.org/10.1007/s11676-015-0037-9.

SILVA, M. M. Diversidade de insetos em diferentes ambientes florestais no município de Cotriguaçu, estado de Mato Grosso. 2009. 111 f. Dissertação (Mestrado em Ciências Florestais) - Curso de PósGraduação em Ciências Florestais, Universidade Federal de Mato Grosso, Cuiabá, 2009.

ZARBIN, P. H. G.; MOREIRA, M. A. B.; FRANCKE, W.; OLIVEIRA, A. R. M. Male-Specific Volatiles Released by the Brazilian Papaya Weevil, Pseudopiazurus obesus: Partial Identification and Evidence of an Aggregation Pheromone. Journal of the Brazilian Chemical Society, Campinas, v. 18, n. 5. p. 1048-1053, 2007. http://dx.doi.org/10.1590/S0103-50532007000500026

WOOD, S. L. The bark and ambrosia beetles of North and Central America (Coleoptera: Scolytidae), a taxonomic monograph. (Great Basin Naturalist Memoirs, n. 6). Cambridge: Harvard University, 1982. 1359 p. 